\title{
4 \\ A Rubbish Man Takes a Wife
}

The Government road passed through the territories of many clans. Talk Eastward and his two companions were going home from the Government Station, and they had just crossed the bridge over the Minj River into their own Kugika territory when they saw two figures climbing the steep hill in front of them. Talk Eastward recognized them as Pain and her brother. He had heard that the white man she was living with had sent her home, and he assumed that the brother had gone to Minj to take her back to Tangilka territory.

Pain was a handsome girl by local standards. As he told me later, a man could be proud of having a wife like that. He himself had one wife, but Eaten was an old woman in his eyes. He had appealed to Two Stay, his elder brother, to help him collect a marriage payment, but Two Stay had said that he could spare no valuables for that purpose. Two Stay was tultul of Burikup subclan and the head of Baimankanim subdivision; surely he could spare some plumes and shells for his brother's marriage payment? But Two Stay had said that Burikup was not a wealthy subclan like Penkup and Koimamkup. Talk Eastward would have to wait. Talk Eastward had waited. His beard had grown, and still he could not get a young wife. Perhaps, Two Stay told him, a girl would carry leg with him and insist on marrying, or a married woman would run away to him. Talk Eastward knew that Two Stay was joking. No girl ever asked him to carry leg. He could not help being ugly and awkward. He would have to get a nice young wife somehow. 
Walking along the road, Talk Eastward remembered that two Burikup men, including a brother of his, had been killed in warfare. They had been helping the Tangilka in a fight against the Dambilika, so the Tangilka should have paid compensation for their deaths. They had never paid. He told this to his companions and outlined a scheme in which he needed their help. He would capture Pain to settle the old score with the Tangilka.

The three men captured the girl. She struggled violently, and the beads she had been wearing around her neck broke and fell to the ground. Talk Eastward told her brother that he was taking her to be his wife, and explained to him the debt the Tangilka owed the Kugika. The brother replied that he did not mind his sister marrying a Kugika man, so long as she did not marry a man of Penkup subclan. The Tangilka had given the Penkup Big Insect's youngest wife, [space in original] and the Penkup had not yet given them a woman in exchange.

Talk Eastward and his companions dragged the unwilling girl to Kondambi and took her as far as Two Stay's house on the track to Gwaip. By the time they arrived, Pain was bruised and cut about from being dragged unwillingly over the pointed palings of pig-fences. A crowd assembled in Two Stay's house to discuss Talk Eastward's acquisition of a bride. They were mostly Burikup people, but Big Insect came when he heard that Talk Eastward had captured a girl of [space in original, presumably Kugika] clan.

'The Pingya are coming tomorrow to pay me compensation for my brother's death,' he told Talk Eastward, naming a clan that lived north of the Wahgi. 'As you know, he was killed when he was staying with them a long time ago. I shall give you part of the death compensation as a contribution towards your marriage payment.'

A native policeman arrived. He had been walking along the Government road and had found Pain's beads, stained with blood. He was directed to Two Stay's house. He satisfied himself that Pain was not seriously injured. Big Insect said that it was local custom to capture girls in this manner. The policeman looked dubious, but he was not a local native so he changed the subject, asking where Pain was going to sleep, for it was now nearly dark.

'Here with me, of course,' Talk Eastward told him. 'She is my wife now.' 
Pain objected loudly. She said that she wanted to sleep with her 'sister'.

'No!' cried Big Insect. 'The Tangilka will hear of it, and they will think that I have slept with the girl.'

The policeman, who could not countenance Talk Eastward's marriage until he had consulted either the Government officer or at least one of the local interpreters at the Government Station, said that Pain should sleep with [space in original]. The two women occupied the little sleeping cubicle of [space in original] house, and Talk Eastward kept watch in the ante-room. He had to get up once during the night to stop Pain from escaping. Big Insect expected Pain's clansmen to arrive the next day bringing the death compensation for Talk Eastward's brother, so that they could retrieve her. They did not arrive, so Talk Eastward took the girl to his house at Gwaip.

Three days later, I came to my house and found the step in the doorway broken, my table upset, and papers scattered on the floor. I learned that Pain, trying to escape from Talk Eastward, had sought sanctuary in my house. Two Stay and some other Burikup men had forcibly removed her. They had called for her to come out, but she had refused, so they had rushed in, seized her, and dragged her out. They had carried her back to Gwaip. I went to visit her. She was sitting in Talk Eastward's garden, under the watchful eyes of Two Stay's wife, Apron. We talked in Neo-Melanesian, which Pain spoke fluently, so that Apron could not understand us.

Pain told me she had decided to let Talk Eastward think she was resigned to marrying him. Then, when he relaxed his guard, she would run away to Whitewood, a Native Medical Assistant. When she was with the European, Pain had discovered that she was pregnant and had taken Whitewood as her lover to counteract this. For pregnancy, in Minj Agamp belief, resulted only from many acts of intercourse with one man, and a girl who was promiscuous was in no danger of having children.

Pain reasoned that it would be useless for her to return to her parents, for Big Insect had already met her father and the Tangilka luluai, and they had both agreed that it would be all right for a Kugika man to marry her. Her father had even told Big Insect to advise Talk Eastward to tie a rope around the girl's waist and fasten her inside his house as if she were a pig, in order to prevent her from escaping. She had tried several times to 
escape. Each night Talk Eastward fastened the door of his house and tried to rape her. Each night she beat him off with sticks she pulled from the fire. Soon, she said, he would grow tired of pestering her.

When Big Insect had met the Tangilka, they had decided that Talk Eastward need not give them a marriage payment until Pain bore a child. If she succeeded in running away before this was possible, the Tangilka undertook to pay Talk Eastward the compensation owing to him for his brother's death. This explained her father's anxiety that Talk Eastward should guard her carefully, for he would rather receive a payment than give one.

Whitewood was transferred to a medical post about four days' walk from Kugika territory, and Pain revised her plans when she heard this. She would run away to her parents. Perhaps they would agree to give her to a Kambilika ${ }^{1}$ man, she preferred him to Talk Eastward.

Pain pretended to be resigned to her marriage, and Talk Eastward soon relaxed his guard. She fled to the Tangilka. The Kugika were amused when they heard that she was again attending courting ceremonies, for they regarded her as a married woman. Her pregnancy was now becoming noticeable, but it was never publicly discussed. Her father advised the Kambilika to come and get her before she ran away to another man. The Kambilika captured her, and her parents put up a token show of resistance then let her go.

The Kugika were quick to remember that the Kambilika, against whom they had fought in the past, were potential enemies. They felt that they were unquestionably right in regarding Pain as Talk Eastward's wife and quite justified in kidnapping a Tangilka girl when her clan had failed to pay compensation for the death of Talk Eastward's brother. They appealed to the Court of Native Affairs at Minj, and they were told to inform Pain, the Kambilika man, and her father that they must attend the court the next day.

The Kugika armed themselves with spears and bows and arrows. They were prepared to fight if the Kambilika offered resistance. They marched along the Government road to the beginning of Kambilika territory. They yodelled from a safe distance, commanding the others to send Pain

1 Pers. comm. from John Burton of 17 August 2013 on the form of these group names. Kambilika is correct. 
and her husband and father. The Kambilika refused, alleging that the Kugika would again capture Pain on the way to Minj. They demanded a police escort. The Kugika returned to Minj and reported that the Kambilika had refused to attend the court unless a policeman were sent to escort them.

Finally, the case was heard. The court ruled that Pain should stay with the Kambilika. Further, the Kugika could not exact compensation for the death of Talk Eastward's brother because the war with the Kambilika had occurred a long time ago, before the Government had come to Minj. The Kugika returned to their homes, muttering that the Kambilika and Tangilka still owed them a bride in exchange for the 'Kugika woman', Pain.

When You Heard's father, a Konumbuga man, died her stepmother married his brother, who became the girl's guardian. He arranged for You Heard's betrothal about a year after she had begun to attend courting ceremonies. He made the arrangements with Good Bird whose marriage to Creamy had initiated an exchange of women between Penkup subclan of Kugika clan and this particular subclan of Konumbuga clan. You Heard was to marry Original Man.

Original Man was shy, for, although he was handsome enough by European standards, he was not attractive to Highlands women. He had given up attending courting ceremonies when he had found that none of the girls was willing to press her nose against his. They never summoned him to carry leg. A Berebuga man by descent, Original Man had lived with the Kugika all his life. Both his parents had been killed by Berebuga witchcraft, and his mother's brother, [space in original] had reared Original Man as his own child and as a fully incorporated member of Kumngakanim sub-subclan.

The girl You Heard used frequently to stay at Minj with an older sister, the wife of a policeman. She carried leg with a coastal native employed as a servant there. When members of the Kugika clan went to Minj on Government work, they heard that she had gone to live with this man and wanted to marry him. They complained to the Court of Native Affairs, and You Heard was ordered to return to her parents until the Pig Ceremonial was over. 
You Heard's parents had gone to Minj for the court case, and on their way home they discussed the possibility of her running away to another man before they could give her to Original Man. Perhaps she would run away to the coastal native again. No one believed her when she protested that she had merely been staying with her sister and that her relations with the coastal native had been confined to carrying leg. Her parents sent a message to Good Bird and [space in original] to come and capture her and marry her to Original Man. Good Bird and some of the Kumngakanim men captured You Heard. Her parents pretended to resist the Kugika, and two of the men were injured slightly. There was no pretence in Your Heard's resistance. She struggled and screamed, pummelled her captors, bit them, and tore their hair. They dragged her to Kondambi and deposited her outside Mountain Tree's house, closely guarded. You Heard's mother followed. She laughed with the two wounded men, apologizing for having to hit them so hard to convince her daughter that she was sorry for her, and promising them that they would have a generous helping of pork from the first pig You Heard reared for Original Man.

You Heard slept that night in Mountain Tree's house with Long, an older Konumbuga woman, guarding her. She made several abortive attempts to escape.

The next day Good Bird and the other men took You Heard back to her parents, who were to bathe her in pigs' fat and decorate her before giving her finally to Original Man. Creamy and Long carried a pig the Kugika had cooked to present to the girl's parents.

You Heard told her family that she did not want to marry yet. She wanted to take part in the Pig Ceremonial, which the Konumbuga were celebrating at the same time as the Kugika. They did not head her, and they beat her whenever she tried to run away. She tried to prevent members of her family from eating the pork the Kugika had brought, knowing that the $k_{i a p s^{2}}$ used the eating of pork as an index of the validity of marriage. Her brother became so angry that he attacked her viciously, inflicting several cuts and bruises. Her step-sister reproved him, 'Don't hit her like that! You are too strong. You'll kill her, and then we shan't get any marriage payment. Let me hit her instead.' She beat the girl until You

2 Patrol officer. 
Heard lost consciousness and fell to the ground. When she recovered, she made a few more futile attempts to escape, and finally allowed her brother to imprison her in her mother's house.

In the morning Good Bird dragged her back, protesting, to Original Man. She had successfully prevented her parents from bathing her with pigs' grease and decking her with ornaments.

More than three weeks passed. During this time, Original Man shut her in the house at night and consummated the marriage by rape. He cut her hair and forcibly removed her woven waistband and armbands and the beads she wore, for a man does not want other men to find his bride attractive. She tried many times to run away, but the Kugika brought her back. Once she managed to reach her parents, but they sent a message to Original Man and he took her back immediately.

One night the guard was relaxed and she was alone with Original Man. She waited until he was asleep, then crept outside and went to her sister at Minj.

The Kugika could not hope to capture You Heard at Minj in the presence of Europeans and police, and she stayed with her sister for nearly two months. The case of Pain was heard at the Court of Native Affairs, and an officer warned the Kugika that if they captured any more girls by force they would all go to jail. The Kugika wanted to continue their Pig Ceremonial and kill their pigs. You Heard's sister and her policeman brother-in-law persuaded her parents to let her stay at home. She returned to her family, and the Kugika were amused to hear that she had resumed courting ceremonies as though she had never been married at all. The policeman threatened to report his parents-in-law if they gave You Heard to Original Man before the end of the Pig Ceremonial.

Original Man was deeply distressed.

'You Heard will go to another man,' he told me. 'I cannot bear to think of her going to another man. If she does, I shall kill her with my hatchet. If I don't kill her, I'll hang myself.' 
We have already met two of You Heard's sisters-the vicious step-sister who lived with her husband near her parents' home, and the kindly policeman's wife at Minj. ${ }^{3}$ You Heard had a third sister, who had recently married a Ngeniga man. Three months after the Court of Native Affairs had reviewed You Heard's case, she went to stay with this third sister. Ngeniga territory adjoins that of the Kugika, who soon learned where You Heard was staying. Early in the morning [space in original], Together Small, and two other men lay in wait for her. When she came out of her sister's house, they took her by surprise and captured her. She struggled with them, but when she injured her wrist she gave in and walked quietly back to Kondambi with them. [space in original] took her to his cooking grove.

I asked [space in original] why they had not waited for the pig-killing. He answered that the officer at the Court of Native Affairs had told the Kugika to wait for three months and then capture You Heard.

'It is a lie!' You Heard hissed.

I told [space in original] that the Kugika had told me the officer had forbidden them to capture You Heard and had advised them that she should not marry until the pig-killing was over. Then [space in original] told me why they had captured her.

You Heard's parents had given the Kugika a pig at the time of Original Man's 'marriage'. This was a pig the Ngeniga had given them as part of the marriage payment for Your Heard's sister. The girl's parents could not themselves eat this pig, because of their part in warfare with the Ngeniga a long time ago, so they had handed it over to the Kugika. They had told them that it would be a convenient time to marry You Heard, because of this circumstances. The Kugika gave You Heard's parents a pig in return, and they had eaten this. You Heard was staying with the Ngeniga when they objected that her parents had never given them a pig in exchange for the one they had given them. They decided to keep You Heard with them and marry her to a Ngeniga man, to compensate for the pig that had not been returned. You Heard's parents and brothers told the Kugika to capture the girl and later give them a pig to present to the Ngeniga.

3 This may reflect an earlier version. 
You Heard was chatting to me when Original Man arrived and went into [space in original] house.

'He is a rubbish man,' she said, an expression of distaste clouding her noble features when she saw him. 'I don't like him. He is no friend of mine, and certainly not my lover. Why did they all have to capture me? Why? I want to run away, but where can I go?'

You Heard did in fact run away, this time to the coastal native with whom she had previously carried leg. Original Man and You Heard's brother reported them to the Government officer, and You Heard was again the subject of a dispute at the Court of Native Affairs. The Kugika told me about it afterwards. The officer had asked You Heard's brother whether he would be agreeable to the coastal native giving him a marriage payment to return to Original Man.

'Definitively not.' The brother of You Heard was adamant. 'His family live at the coast, and I can't visit them.'

Original Man supported him, saying, 'I don't want the marriage payment back. I want to marry her myself.'

'Shut up!' said the officer. 'It is plain that You Heard doesn't like you.'

You Heard was told to go home and stay there until she found a local native she wanted to marry. In fact, she was told, she could stay at home until she died, if she wanted to stay single. 
This text is taken from Wives and Wanderers in a New Guinea Highlands Society: Women's lives in the Wahgi Valley, by Marie Olive Reay, published 2022 by ANU Press, The Australian National University,

Canberra, Australia.

doi.org/10.22459/WWNGHS.2022.04 